\title{
PRELIMINARY ELECTROPHORETIC ANALYSIS OF HUMAN GASTRIC JUICE ${ }^{1,2}$
}

\author{
By MARIAN H. MACK, STEWART WOLF, ${ }^{3}$ AND KURT G. STERN
}

\author{
(From the New York Hospital and the Department of Medicine, Cornell University Medical \\ College, and from the Department of Chemistry, Polytechnic Institute of \\ Brooklyn, Brooklyn, N. Y.)
}

(Submitted for publication February 9, 1953; accepted May 22, 1953)

In a recent publication (1) electrophoretic data were reported on two mucoproteins obtained by fractionation of human gastric juice according to the method of Glass and Boyd (2). One of the separated components, "glandular mucoprotein," contains an acid mucopolysaccharide as a prosthetic group, while the other separated mucoprotein, termed "mucoproteose," contains a neutral polysaccharide as a prosthetic group. Both mucoproteins were found to be fairly homogeneous electrophoretically and both were negatively charged in the $\mathrm{pH}$ range studied (5.0 to 8.5); however, the "glandular mucoprotein" migrated with an exceptionally high mobility and the "mucoproteose" with an exceptionally low mobility. The present study was undertaken to ascertain whether or not the electrophoretic data reported on these two chemically fractionated mucoproteins could be correlated with the electrophoretic pattern of whole human gastric juice.

\section{METHOD}

Fasting gastric juice was obtained by intubation of healthy volunteers and patients with peptic ulcer. The subjects were urged not to swallow saliva. Specimens discolored by bile were discarded. The gastric juice collected was then treated by one of the following methods: Method $A$ : Freshly collected juice was filtered, neutralized to a $\mathrm{pH}$ of approximately 7 by adding dropwise, with twirling, $1 \mathrm{~N}$ sodium hydroxide, dialyzed for 24 hours against cold ( $5^{\circ}$ to $10^{\circ}$ C.) running tap water, dialyzed for 24 hours against cold ( $2^{\circ}$ to $5^{\circ}$ C.) distilled water, and then dried by lyophilization. Method $B$ : Immediately after

1 This report contains a portion of a thesis submitted by Marian H. Mack in partial fulfillment of the requirements for the degree of Master of Science in Chemistry at the the Polytechnic Institute of Brooklyn.

2 Supported in part by a grant from the National Cancer Institute of the National Institutes of Health, U. S., Public Health Service.

3 Present address : Department of Medicine, University of Oklahoma, School of Medicine, Oklahoma City, Oklahoma. collection, the gastric juice was placed in a refrigerator maintained at $2^{\circ}$ to $5^{\circ} \mathrm{C}$. At a later time, varying from a few hours to several days, the gastric juice was filtered, dialyzed against cold running tap water and distilled water, and lyophilized.

The prepared material was then dissolved in buffer. Both phosphate and veronal buffers were used; an ionic strength of $0.1 \mathrm{M}$ was maintained in all experiments. In the initial experiments the concentrations of the protein solutions varied from 1 per cent to 2 per cent; in later experiments concentrations of 2.5 per cent to 5 per cent were used. At these higher concentrations the protein solutions were turbid but could be cleared by centrifuging for 15 minutes at 15,000 to $20,000 \mathrm{RPM}$. It is recognized that this maneuver may remove some of the less soluble components but loss of some material would not vitiate the inferences drawn from this study. All protein solutions were dialyzed against the buffer used through Visking tubing tied off at both ends; if this precaution was not taken the solutions within the tubing swelled and consequently became more dilute. Specimens of saliva were immediately filtered, dialyzed against cold running tap water and cold distilled water, and lyophilized. This material was then dialyzed against the buffer prior to electrophoresis. The majority of the electrophoresis experiments were carried out with an Aminco portable electrophoresis apparatus and a clinical cell. A few additional experiments. were performed with the aid of an Aminco-Stern electrophoresis apparatus and an analytical cell, and with a Klett electrophoresis apparatus and an analytical cell. In keeping with custom, mobilities were calculated from the descending limb and expressed in units $\times 10^{-5} \mathrm{~cm}^{2} \mathrm{sec}^{-1}$ volts $^{-1}$. Relative concentration was grossly estimated on the basis of planimeter measurements of the peaks in the ascending limb.

\section{RESULTS}

\section{Electrophoretic Patterns}

1. Electrophoretic patterns at varying values of $p H$. The results of a series of experiments on a single preparation, obtained by Method B, at four different $\mathrm{pH}$ levels and at a potential gradient of from 5.1 to 5.5 volts per $\mathrm{cm}$., are listed in Table I. These experiments were carried out with a Klett electrophoresis apparatus and an 
analytical cell. Although the patterns were essentially the same at all $\mathrm{pH}$ levels, the best resolution was achieved at the highest $\mathrm{pH}$ value (8.5). The electrophoretic pattern of the experiment performed with 0.1 ionic strength phosphate buffer and at a $\mathrm{pH}$ of 6.1 and a protein concentration of 1.4 per cent is shown in Figure 1. To facilitate discussion the various peaks are arbitrarily identified by symbols, corresponding to those used in Table I.

An inspection of Table I reveals that the components migrate at a higher mobility in phosphate buffer of $\mathrm{pH} 6.9$ than in veronal buffer of $\mathrm{pH} 8.5$. This anomalous result was also observed by Pugh, Glass and Wolf (1) in their electrophoretic studies of the fractionated gastric mucoproteins. On the basis of the results listed in Table I, all ensuing electrophoresis experiments were carried out in 0.1 ionic strength veronal buffer of $\mathrm{pH} 8.5 \pm 0.1$. These conditions were deemed the best for analysis to achieve optimal resolution and greatest protein concentration (the solubility was greater at a higher $\mathrm{pH}$ ).

2. Patterns in the gastric juice of healthy subjects. Six electrophoresis experiments on material obtained from the gastric juice of healthy subjects were carried out in veronal buffer at a hydrion concentration of $8.5 \pm 0.1$ and an ionic strength of 0.1 . The protein concentrations varied from 1.1 per cent to 5.0 per cent. The results are listed in Table II which indicates the range of mobilities and the concentrations roughly estimated from planimetric measurements of the peaks.

3. Patterns in the gastric juice of patients with duodenal ulcer. Fourteen experiments were performed on material obtained from the gastric juice of patients with duodenal ulcer. These were run at the same $\mathrm{pH}$ and in the same range of protein concentration as the observations on healthy subjects. The results are listed in Table II where in comparison with the healthy subjects it is evident that the electrophoretic pattern is the same as regards mobility but among the ulcer patients the concentration of the G-1 component appears to be significantly greater and the concentration of the G-3 component significantly smaller than among the healthy subjects.

4. Electrophoretic pattern of saliva. Because
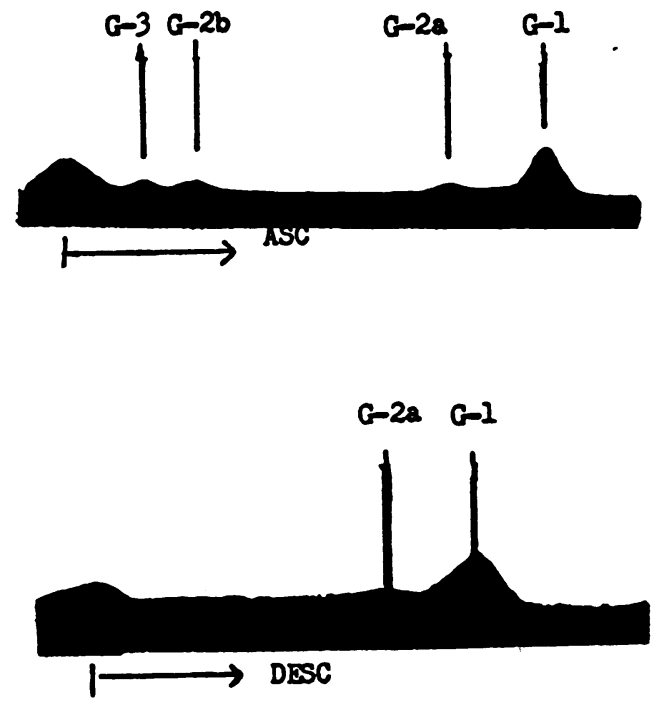

Fig. 1. The Electrophoretic Pattern of Gastric Juice From a Healthy Subject in 0.1 Ionic Strength Phosphate Buffer at pH 6.0 and a Protein Concentration of 1.4 Per Cent

it was virtually impossible to prevent some degree of salivary contamination during the collection of the gastric juice, it seemed important to determine the electrophoretic pattern of saliva. Figure 2 presents the electrophoretic pattern of pooled human saliva after migration for 12,720 seconds in $0.1 \mathrm{M}$ veronal buffer at $\mathrm{pH} 8.5$ and in protein concentration of 3.0 per cent. The mobilities (calculated from the descending limb) of the S-1 and S-2 components are $-4.2 \times 10^{-5}$ and $-2.4 \times$ $10^{-5} \mathrm{~cm}^{2} \mathrm{sec}^{-1}$ volts $^{-1}$, respectively. These mobilities are of the same order of magnitude as the G-2 group of proteins. In addition, the resolution of the S-2 component of this saliva preparation into two components on the ascending limb is very similar to that of the G-2a component of the gastric juice preparation.

TABLE I

Mobilities of components at varying hydrion concentrations

\begin{tabular}{|c|c|c|c|c|c|c|}
\hline \multirow[b]{2}{*}{ Buffer } & \multirow[b]{2}{*}{ pH } & \multirow{2}{*}{$\begin{array}{c}\text { Protein } \\
\text { conc. } \\
\%\end{array}$} & \multicolumn{4}{|c|}{ Mobility (Desc. limb)* } \\
\hline & & & $\overline{\text { G-1 }}$ & G-2a & G-2b & G-3 \\
\hline $\begin{array}{l}\text { Phosphate } \\
\text { Phosphate } \\
\text { Phosphate } \\
\text { Veronal }\end{array}$ & $\begin{array}{l}5.1 \\
6.1 \\
6.9 \\
8.5\end{array}$ & $\begin{array}{l}1.6 \\
1.4 \\
1.6 \\
1.4\end{array}$ & $\begin{array}{l}6.2 \\
8.9 \\
9.8 \\
7.8\end{array}$ & $\begin{array}{l}4.3 \\
6.8 \\
7.7 \\
4.7\end{array}$ & $\begin{array}{l}\mathrm{T} \\
1.2 \\
1.6\end{array}$ & $\begin{array}{l}. \\
.7 \\
.8\end{array}$ \\
\hline
\end{tabular}

* Mobilities expressed in units of $-u \times 10^{-5} \mathrm{~cm}^{2} \mathrm{sec}^{-1}$ volts ${ }^{-1}$.

† Component not resolved. 
TABLE II

Range of mobility calculated from experiments on material from the gastric juice of normal individuals and patients with duodenal ulcer

\begin{tabular}{llrlrrr}
\hline & \multicolumn{2}{c}{ Controls } & & \multicolumn{2}{c}{ Clcer patients } \\
\cline { 2 - 3 } \cline { 6 - 7 } Component & Mobility & $\begin{array}{c}\text { Relative } \\
\text { conc. }\end{array}$ & & Mobility & $\begin{array}{c}\text { Relative } \\
\text { conc. }\end{array}$ \\
\hline G-1 & $7.4-8.4$ & $5-15$ & & $7.2-8.4$ & $10-25$ \\
G-2a & $3.5-5.5$ & $20-50$ & & $3.3-5.7$ & $10-25$ \\
G-2b & $1.0-2.0$ & $5-10$ & & $1.0-2.0$ & $5-10$ \\
G-3 & $0.4-1.0$ & $20-40$ & & $0.4-1.0$ & $5-15$ \\
\hline
\end{tabular}

The possibility that the G-2 group proteins in gastric juice represented solely contaminating saliva was ruled out by finding a small diffuse G-2 peak, of a size comparable to that seen in the gastric juice of intact subjects, in the gastric juice of Tom, an individual with a gastric fistula and an occluded esophagus (3). The ascending limb of the electrophoretic pattern, after 5,070 and 9,810 seconds, is shown in Figure 3 ; the mobilities of the G-1, G-2, and G-3 components were -8.4 , -4.7 , and $-1.0 \times 10^{-5} \mathrm{~cm}^{2}$ sec. $^{-1}$ volts $^{-1}$, respectively.

II. Attempts to Identify "Glandular Mucoprotein" and "Mucoproteose" in the Electrophoretic Pattern of Human Gastric Juice

One gram of material prepared by Method B

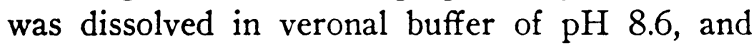
electrophoresis determinations were carried out on the first aliquot of this solution alone, on a second aliquot to which "glandular mucoprotein" had been added, and on a third aliquot to which "mucoproteose" had been added. The amounts

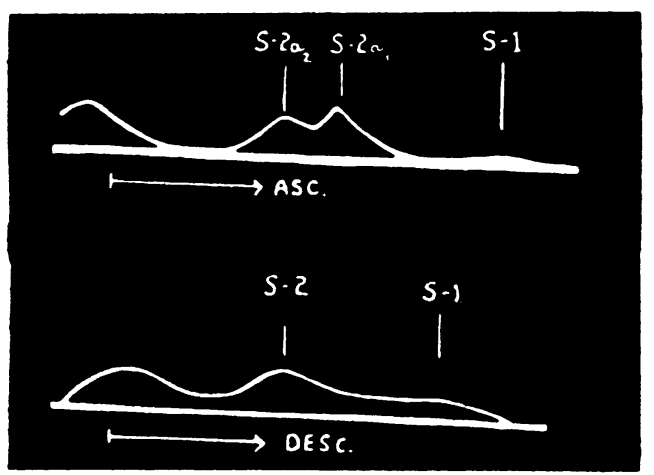

Fig. 2. The Electrophoretic Pattern of Human Saliva in a 0.1 Ionic Strength Veronal Buffer at pH 8.5 and a Protein Concentration of 3.0 Per Cent

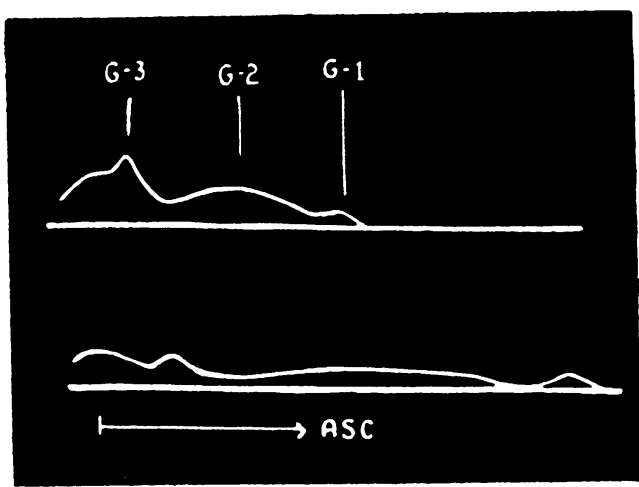

Fig. 3. The Electrophoretic Pattern of the Gastric Juice of Tom Uncomtaminated by Saliva Shown in the Ascending Limb After 5,070 and 9,810 Seconds

and relative concentrations of the lyophilized gastric proteins (L.G.P.), the "glandular mucoprotein" (MPN), and the "mucoproteose" (MPTS) in each solution are tabulated in Table III.

The electrophoretic pattern of the plain gastric specimen is shown in Figure 4, upper tracing. It is a typical pattern, consisting of a fairly homogeneous leading component, G-1; a very inhomogeneous, diffuse center component, G-2a; a slight amount of protein forming a fairly slow peak, G-2b; and a fairly homogeneous, slowest moving component, G-3. The added MPN formed a peak about midway between components G-1 and G-2a (Figure 4, middle tracing). The added MPTS increased the area of the slowest moving component, G-3 (Figure 4, lower tracing). The mobilities of the components (calculated from the descending limb) are given in Table IV.

The MPN analyzed in a separate experiment at a concentration of 1.8 per cent migrated as a single component and appeared more homogene-

TABLE III

A mounts and relative concentrations of protein in the plain gastric specimen $(A)$ and in those to which "glandular mucoprotein" (B) and mucoprotense (C) had been added

\begin{tabular}{|c|c|c|c|c|c|c|c|}
\hline \multirow[b]{2}{*}{$\begin{array}{c}\text { Expt. } \\
\text { no. }\end{array}$} & \multirow[b]{2}{*}{$\begin{array}{l}\text { Mg. of } \\
\text { L.G.P. }\end{array}$} & \multirow{2}{*}{$\begin{array}{l}\text { Mg. of } \\
\text { MPN } \\
\text { added }\end{array}$} & \multirow[b]{2}{*}{$\begin{array}{l}\text { Mg. of } \\
\text { MPTS } \\
\text { added }\end{array}$} & \multirow{2}{*}{$\begin{array}{l}\text { Total } \\
\text { prot. } \\
\text { conc.* } \\
\text { \% }\end{array}$} & \multicolumn{3}{|c|}{ Conc. of components } \\
\hline & & & & & L.G.P. & $\underset{\%}{\text { MPN }}$ & $\underset{\%}{\text { MPTS }}$ \\
\hline $\mathrm{A}$ & 4 & - & - & 2 & 2.9 & - & - \\
\hline B & 26 & 134 & - & & 2. & 1.0 & - \\
\hline C & 268 & - & 134 & 3.0 & 2.0 & - & 1.0 \\
\hline
\end{tabular}

* Total protein concentration was calculated by dividing total dry weight of all protein material by the total volume of protein solution after dialysis. 
ous than the MPN peak of Experiment B. The mobility of the MPN in this experiment was $-6.9 \times 10^{-5} \mathrm{~cm}^{2} \mathrm{sec}^{-1}$ volts $^{-1}$, as compared to the mobility of $-5.5 \times 10^{-5}$ in Experiment $\mathrm{B}$. The MPTS analyzed in a separate experiment at a concentration of 1.5 per cent migrated as a single component, with a mobility of $-0.8 \times 10^{-6} \mathrm{~cm}^{2}$ sec. $^{-1}$ volts $^{-1}$.

III. Electrophoretic Analysis of Protein Preparations Obtained by Fractionation of Gastric Juice According to the Method of Glass and Boyd (2)

Bile-free gastric juice from a fasting patient with duodenal ulcer was collected and filtered at twenty minute intervals over a three hour period. This gastric juice was then divided into three equal portions and fractionated as follows: Fraction 1 was obtained by treating one portion by method as described above. Fraction 2 was obtained by treating a second portion by the first step in the Glass and Boyd method (2) ; i.e., removal of contaminants by precipitation with trichloracetic acid, and then was dialyzed and

A

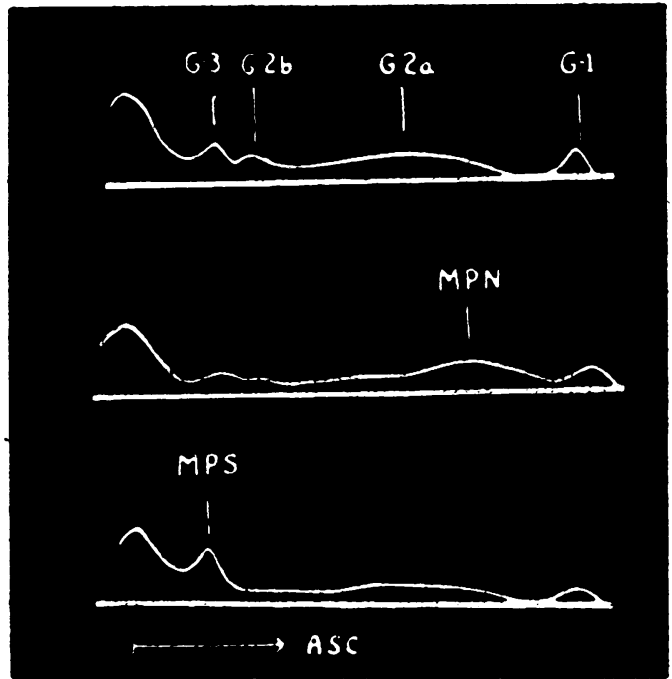

Fig. 4. A: The Electrophoretic Pattern of Gastric Juice from a Healtey Subject in 0.1 Ionic Strength Veronal Buffer at pH 8.6 and a Protein ConcentraTION OF 3.9

B: The Same After Adpition of Glandular MUCOPROTEIN

C: The Same as A After Adprtion of Mucoproteose
TABLE IV

Mobilities of components in the plain gastric specimen $(A)$ in those to which glandular mucoprotein $(B)$ and mucoproteose $(C)$ had been added

\begin{tabular}{cccc}
\hline & \multicolumn{3}{c}{ Mobility $\left(-\mathrm{u} \times 10^{-6} \mathrm{~cm}^{2}\right.$ sec. $^{-1}$ volts $\left.^{-1}\right)$} \\
\cline { 2 - 4 } Component & Exp. A & Exp. B & Exp. C \\
\hline G-1 & 7.4 & 7.5 & 7.4 \\
G-2a & 4.3 & $*$ & $*$ \\
G-2b & 1.0 & 1.2 & $\dagger$ \\
G-3 & .5 & .7 & .6 \\
MPN & - & 5.5 & - \\
\hline
\end{tabular}

* Component too diffuse for accurate calculation.

† Component missing, probably obscured by large MPTS peak.

lyophilized. Fraction 3 was obtained by treating a third portion by the first two steps in the Glass and Boyd method, i.e., removal of contaminants with trichloracetic acid and precipitation of "mucin" with acetone. The "mucin" was then dissolved in $0.1 \mathrm{~N}$ sodium hydroxide, was dialyzed, and then lyophilized.

An electrophoresis experiment was performed on each of the fractions obtained in the manner described above. The Aminco portable electrophoresis apparatus and clinical cell were employed, and the analyses were carried out using 0.1 ionic

a

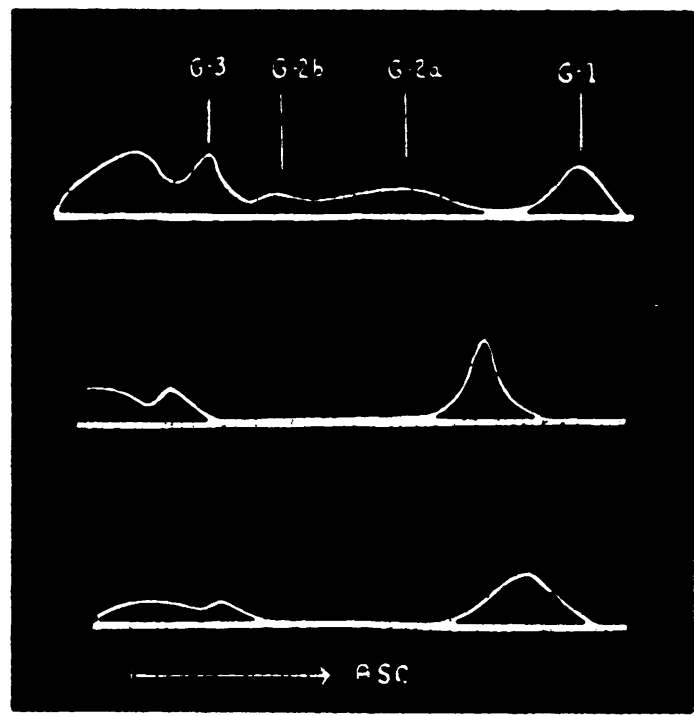

Fig. 5. A: The Ascending Limb of the Electrophoretic Pattern of Human Gastric Juice

B: The Same after Treatment with Trichloracetic Acid

C: The Same as A after Treatucent with Both Trichloracetic ACId aNd Acetone 
TABLE V

Mobilities of protein components in fractions separated by method of Glass and Boyd

\begin{tabular}{|c|c|c|c|c|}
\hline \multirow[b]{2}{*}{ Fraction } & \multicolumn{3}{|c|}{$-\mathrm{a} \times \underset{\text { volts }}{10^{-1}} \mathrm{~cm}^{2} \mathrm{sec}^{-1}$} & \multirow{2}{*}{$\begin{array}{c}\text { Protein } \\
\text { conc.* } \\
\%\end{array}$} \\
\hline & G-1 & G-2 & G-3 & \\
\hline \multirow{3}{*}{$\begin{array}{l}\text { 1. Plain gastric specimen } \\
\text { 2. Treated with trichloracetic } \\
\text { acid } \\
\text { 3. Treated with trichloracetic } \\
\text { acid and acetone }\end{array}$} & 7.7 & 4.7 & 1.5 & 2.5 \\
\hline & 5.5 & 0 & .4 & 2.4 \\
\hline & 7.1 & 0 & 1.8 & 1.8 \\
\hline
\end{tabular}

* Protein concentration calculated on basis of dry weight of lyophilized material, with assumption that all material is protein in nature.

strength veronal buffer of $\mathrm{pH}$ 8.5. The ascending limb electrophoretic patterns of the three fractions are shown in Figure 5, and the mobilities of the designated components (calculated from the descending limb) are tabulated in Table V.

The electrophoretic pattern of whole gastric juice proteins (Fraction 1) exhibited five maxima in the refractive index gradient curve, one of them representing the stationary boundary (Figure 5), upper tracing. The component of highest mobility, G-1, was fairly homogeneous and represented 14 per cent of the total concentration of material. The mobility of this G-1 protein was of the same order of magnitude in Fractions 1, 2, and 3. However, in Fraction 2 it represented 35 per cent and in Fraction 3, 40 per cent of the total concentration. In addition, the peak was sharper and more symmetrical in the electrophoretic diagram of Fraction 2 than in either Fraction 1 or 3.

\section{COMMENT}

It is as yet impossible to state whether the change in mobility and symmetry of the G-1 component is due to denaturation of the proteins during the fractionation procedure, to the action of proteolytic enzymes present in gastric juice, or to some other cause. At the present time, studies are in progress to obtain pure components by utilizing a modification of the low temperatureethanol fractionation technique used by Cohn and his associates in the fractionation of blood (4).

The G-2 group proteins were evident in the electrophoretic pattern of Fraction 1 ; their mobilities were of the same order as previously calculated. However, in the electrophoretic patterns of Fraction 2 and 3 no peaks corresponding to the G-2 group proteins were evident. Glass and Boyd have demonstrated (2) that the trichloracetic acid removes contaminating salivary proteins, and since it has been shown above that salivary proteins are related to the G-2 group proteins, the absence of any G-2 group in the electrophoretic patterns of Fractions 2 and 3 is not altogether surprising. However, it should be stressed that the trichloracetic acid removes the G-2 proteins of gastric origin as well as those of salivary origin.

The relative concentration of the G-3 protein, as determined from the electrophoretic diagrams, was virtually identical for Fractions 1,2 , and 3 . In addition, in all three fractions the mobilities of this component were of the same order of magnitude and the symmetry was essentially the same.

\section{DISCUSSION AND SUMMARY}

The electrophoretic analyses of the concentrated gastric juice of normal individuals and of patients with duodenal ulcer demonstrated the presence of at least five different proteins whose relative concentrations varied considerably.

It is recognized that the procedures required in the preparation of the material for electrophoretic analysis may have denatured or in some way altered the electrical properties of the proteins. The component with the highest mobility was designated as G-1. Fairly homogeneous, it occurred in higher concentration in the gastric juice of patients with duodenal ulcer than in that of normal individuals. Glass, Boyd, and Svigals (5) had earlier found a higher concentration of "glandular mucoprotein" (MPN) in juice from individuals with duodenal ulcer than from healthy subjects. This correlation, plus the results of the fractionation of gastric juice by the Glass and Boyd method reported above, suggests that the G-1 component is related to glandular mucoprotein. The fact that prepared "glandular mucoprotein" when added to lyophilized gastric juice protein migrated as a separate component, suggests that the glandular mucoprotein is a form of the G-1 component denatured by the drastic conditions of its preparation from a 60 per cent acetone solution at room temperature.

The resolution, mobilities, and relative concentrations of the group of proteins designated as the G-2 components varied considerably, with the 
number of separate peaks varying from one to three. The peaks of these proteins were diffuse, indicating inhomogeneous, low molecular weight material. Although it was demonstrated that contaminating salivary proteins contribute to the G-2 group components, the experiment on the juice of the gastric fistulous subject with occluded esophagus suggests that gastric juice proteins also contribute to this group.

The peak designated as the G-3 component indicated the presence of a fairly homogeneous protein, migrating at a very low mobility. This component was electrophoretically identical with "mucoproteose" (MPTS) of Glass and Boyd. The studies of material partly fractionated by the Glass and Boyd method suggest that the mucoproteose concentration, as determined by chemical analysis, includes in part dialyzable, low molecular weight material. This fraction of mucoproteose could, of course, not be examined electrophoretically.

\section{CONCLUSIONS}

With the limitations in mind that the preparatory procedures may have altered the proteins, it may be stated that the electrophoretic pattern of whole human gastric juice reveals the presence of at least five electrophoretically distinct proteins, present in varying concentrations. The compo- nent of highest mobility seems to be related to, but is not identical with, the "glandular mucoprotein" of Glass and Boyd. The component of lowest mobility is electrophoretically identical with the "mucoproteose" of Glass and Boyd.

\section{REFERENCES}

1. Pugh, B. L., Glass, G. B. J., Wolf S., Electrophoretic studies of the mucin fractions from the human gastric juice. Proc. Soc. Exper. Biol. \& Med., 1952, 79, 674.

2. Glass, G. B. J., and Boyd, L. J., The three main components of the human gastric mucin: Dissolved mucoproteose, dissolved mucoprotein, and mucoid of the gastric visible mucus. Gastroenterology, 1949, 12, 821; Ibid., 1949, 12, 835 ; Ibid., 1949, 12, 849.

3. Wolf, S., and Wolff, H. G., Human Gastric Function : An Experimental Study of Man and His Stomach, Oxford Univ. Press, New York, 2nd Ed., 1947.

4. Cohn, E. J., Luetscher, J. A., Jr., Oncley, J. L., Armstrong, S. H., Jr., and Davis, B. D., Preparation and properties of serum and plasma proteins. III. Size and charge of proteins separating upon equilibration across membranes with ethanol-water mixtures of controlled $\mathrm{pH}$, ionic strength and temperature. J. Am. Chem. Soc., 1940, 62, 3396.

5. Glass, G. B. J., Boyd, L. J., and Svigals, C. S., The absence of glandular mucoprotein and the presence of mucoproteose from surface epithelium in the gastric juice of patients with pernicious anemia. Bull. New York M. Coll., Flower \& Fifth Ave. Hosps., 1950, 13, 15. 